\title{
Personalien- und Tagesnachrichten
}

H.Prof. Herr Prof. Cords in Köln wird seinen Spaltlampenkurs in sechs aufein-anderfolgenden Samstag-Nachmittagen von Mitte Juni bis Ende Juli wieder-holen. 